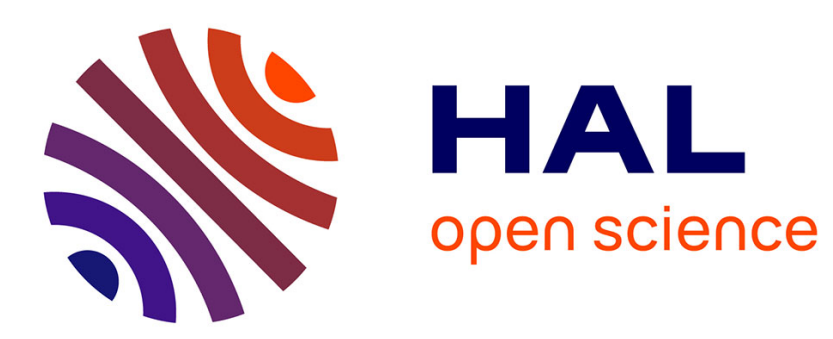

\title{
Thermal Strain of Green Hinoki Wood: Separating the Hygrothermal Recovery and the Reversible Deformation
}

Sandrine Bardet, Joseph Gril, Keisuke Kojiro

\section{To cite this version:}

Sandrine Bardet, Joseph Gril, Keisuke Kojiro. Thermal Strain of Green Hinoki Wood: Separating the Hygrothermal Recovery and the Reversible Deformation. Models and Methods in Civil Engineering, Lecture Notes in Applied and Computational Mechanics, Springer verlag, pp.6, 2012. hal-00789662

\section{HAL Id: hal-00789662 \\ https://hal.science/hal-00789662}

Submitted on 18 Feb 2013

HAL is a multi-disciplinary open access archive for the deposit and dissemination of scientific research documents, whether they are published or not. The documents may come from teaching and research institutions in France or abroad, or from public or private research centers.
L'archive ouverte pluridisciplinaire HAL, est destinée au dépôt et à la diffusion de documents scientifiques de niveau recherche, publiés ou non, émanant des établissements d'enseignement et de recherche français ou étrangers, des laboratoires publics ou privés. 
Bardet S., Gril J., Kojiro K. (2012) Thermal Strain of Green

Hinoki Wood: Separating the Hygrothermal Recovery and the Reversible Deformation, in: Mechanics, Models and Methods in Civil Engineering, Lecture Notes in Applied and Computational Mechanics, Frémond M,

Maceri F. (ed), vol. 61, p. 157-162

\title{
Thermal strain of green Hinoki wood: separating the hygrothermal recovery and the reversible deformation
}

\author{
Sandrine Bardet ${ }^{1}$, Joseph Gril ${ }^{1}$, Keisuke Kojiro ${ }^{2}$ \\ 1 Laboratoire de Mécanique et Génie Civil, \\ Université Montpellier II, cc 048, \\ Place Eugène Bataillon, \\ 34095 Montpellier Cedex 5, France \\ 2 Laboratory of Wood Technology, \\ Kyoto Prefectoral University (KPU), \\ Kyoto, 606-8522, Japan
}

\begin{abstract}
Heating of green wood involves a complex set of deformation processes, including reversible thermal strain, reversible shrinkage due to decrease of moisture content, and irreversible viscoelatic recovery of growth stress activated by temperature called hygrothermal recovery (HTR). Experimental tests were performed on small Japanese Cypress specimens oriented in the three principal R, T, L directions, using a Thermo Mechanical Analyser. The analysis allowed the separation of the hygrothermal recovery from the reversible components of the deformation.
\end{abstract}

\section{Introduction}

The viscoelastic behaviour of wood, as a polymeric material, is related to its molecular constitution. For instance, the considerable drop of rigidity of green wood from 60 to $100^{\circ} \mathrm{C}$ can be explained by the glassy transition of lignin [1,2]. However, when experimental data are analysed with some detail, a number of difficulties arise. One of them is the variability of the material, summarize as due to its "biological origin". The first heating of green wood (never dried wood) leads to a tangential swelling and a radial shrinkage. This abnormal thermal strain results from a superposition of at least four deformation processes: (i) standard thermal expansion; (ii) shrinkage due to the decrease of the fibre saturation point; (iii) viscoelastic recovery of growth stress; (iv) thermal degradation. Whereas (i) and (ii) are reversible processes relative to temperature change, (iii) and (iv) are irreversible. For moderate heating leading to negligible degradation, (iii) is usually dominating in the case of fresh green wood. This phenomenon first described by Kübler [3] was called "hygrothermal recovery" (HTR) by Yokota and Tarkow [4]. Locked-in strains are first generated in the maturation process and then by the loading history applied to the wood before tree felling. Wood maturation corresponds to biochemical processes happening after 
the deposition of secondary layers, such as lignin polymerisation, completion of cellulose crystallisation or cross-linking in the amorphous regions of the cell-wall material. This phenomenon induces maturation strains which can be simulated by presuming that rheological conditions during maturation are equivalent to those of hygrothermal treatment [5]. Loading history applied to the wood depends on the action of subsequently formed wood layer, new cells are submitted to longitudinal tension and previous cells to compression. Finally, wood in the tree is pre-strained: near the bark wood is under tension in the longitudinal direction, under compression in the tangential direction and free in the radial direction, near the pith wood is under compression in the longitudinal direction and under tension in both tangential and radial direction.

The locked-in strains due to maturation and stress history are partially released by cutting specimens from the tree, this is equivalent to unloading the material; therefore, from a mechanical point of view this is a recovery. Remaining locked-in strains are released by heating the wood in water or steam, this viscoelastic recovery is thermally activated.

Previous works dealing with hygrothermal recovery [5-7] focused on anisotropy of the process and influence of the location in the tree. It is now admitted that a thermal treatment over the glassy transition of lignins leads to a irreversible deformation equals to $+0.5 \%$ to $1 \%$ in $\mathrm{T}$ direction, $-0.15 \%$ in $\mathrm{R}$ direction, $0.1 \%$ in L direction. Nevertheless, some questions are still remaining about the time and temperature required to fully accomplished the HTR. It was therefore decided to measure HTR on a Japanese softwood in directions $(\mathrm{R}, \mathrm{T}, \mathrm{L})$ and to study the influence of distance from pith (specimen from outer zone, middle zone and inner zone). In this paper, results obtained in tangential direction are presented.

Furthermore, a modelling of viscoelastic behavior of green wood is developed. These experimental data should be used to define a pre-strained mechanical state of green wood in order to obtain an initial state

\section{Material and methods}

Specimens were cut from a Japanese Cypress (Chamaecyparis obutusa) recently felled, with dimensions $20 \mathrm{~mm}$ in the observed direction $(\mathrm{T})$ and perpendicular section $4 \times 4 \mathrm{~mm}^{2}$. Outer, middle and inner zone are defined in figure 1 . They were kept in water at $3^{\circ} \mathrm{C}$ before testing. The testing device was a Thermo Mechanical Analyser (TMA) equipped with compression attachment, so that the specimen were submitted to a slight compression stress (equivalent to $5 \mathrm{~g}$ ) and immersed in water, the system controlling the temperature both during heating and cooling. Variations of dimensions were recorded with an accuracy of $0.01 \mu \mathrm{m}$. The specimens were submitted to a thermal process as follows: heating at $3^{\circ} \mathrm{C} / \mathrm{min}$ from room temperature to $90^{\circ} \mathrm{C}$, constant temperature during $240 \mathrm{~min}$, cooling at $3^{\circ} \mathrm{C} / \mathrm{min}$ to $25^{\circ} \mathrm{C}$. This process was repeated one or 2 times.

\section{Results and discussion}

A typical curve for a tangential test is given in figure 2. The first heating leads to a large increase of dimension (around $20 \mu \mathrm{m}$ ) related mainly to hygrothermal recovery 


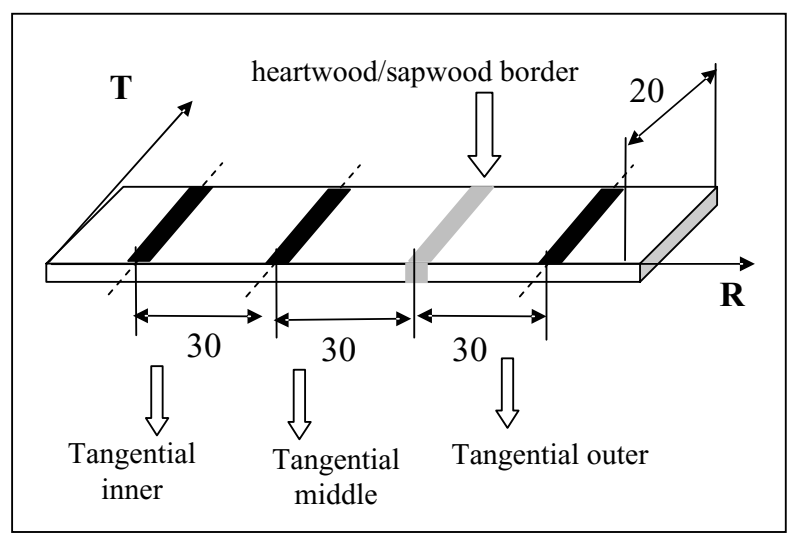

Fig. 1. Samples from outer, middle and inner zone.

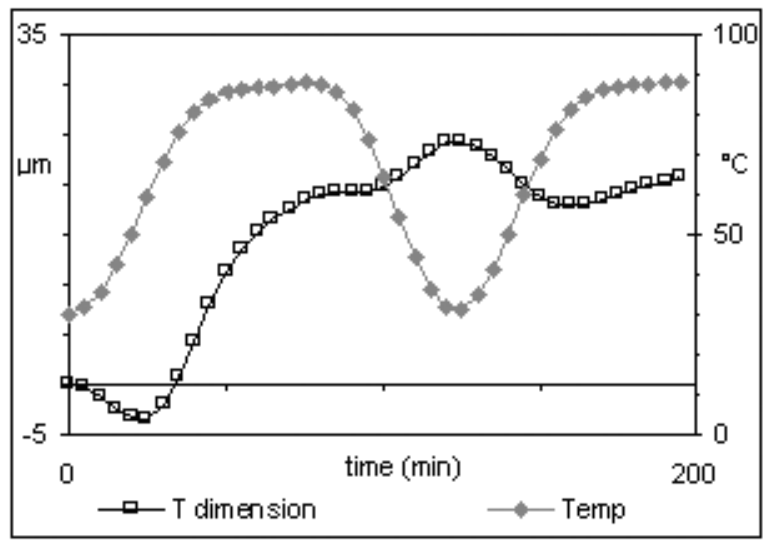

Fig. 2. Typical hygrothermal recovery curve for tangential test, outer zone (variations of dimensions and temperature against time).

of growth strains. The first cooling causes a slight additional increase of dimension explained by an increase of fibre saturation point leading to a swelling (reversible phenomenon). This is made evident by the second heating causing a slight decrease of dimension corresponding to the reverse phenomenon. The following method to separate hygrothermal recovery and reversible deformation is applied:

- evolution of reversible strain with temperature is extracted from the first cooling phase corresponding to the reversible deformation (correcting function),

- evolution of strain during the first heating phase is corrected using the former data and irreversible strain and rate against temperature are calculated.

Fig. 3 presents the rough curve, the correcting function and the corrected curve for a tangential test, deformation of the specimen is plotted against temperature. This method is applied to tangential tests from outer, middle and inner zone.

The influence of radial position is given by figure 4 . The mean value of total and irreversible strain at $90^{\circ} \mathrm{C}$ (at the end of the heating phase) for 2 or 3 tests is 
plotted for inner, middle and outer zone. Hygrothermal recovery (i.e., irreversible strain) decreases with distance from pith from $0.25 \%$ near the pith to $0.11 \%$ near the bark. This is relevant with growth stress distribution described by Kübler.

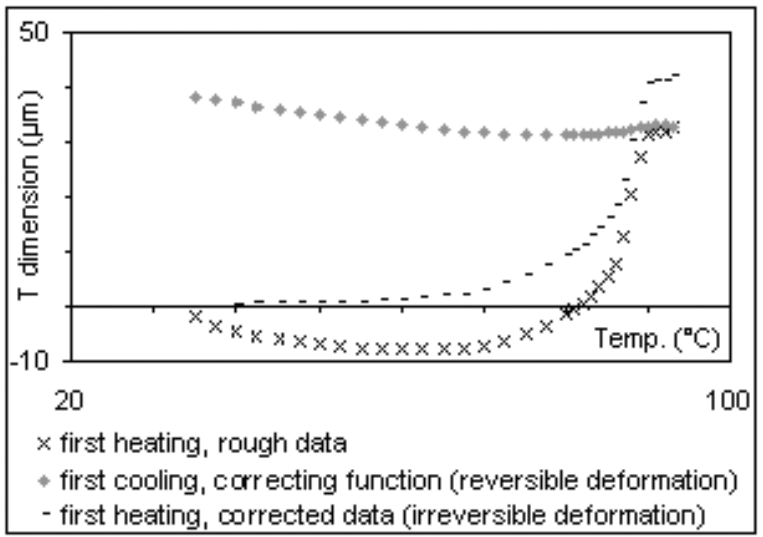

Fig. 3. Separation of irreversible hygrothermal recovery and reversible deformation (variations of dimensions against temperature).

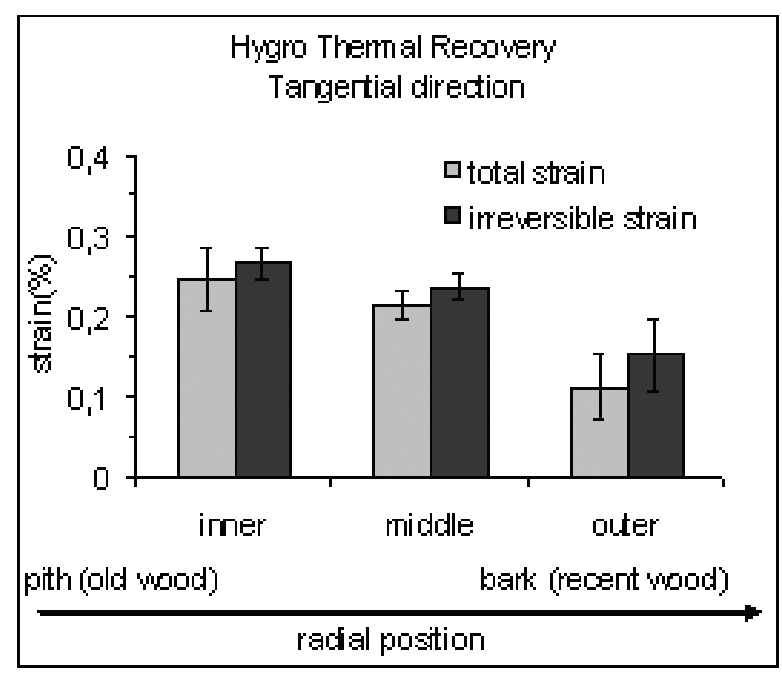

Fig. 4. Mean value of total strain and irreversible strain at $90^{\circ} \mathrm{C}$ for inner, middle and outer samples (vertical lines give standard deviation).

The previous results show that rheological history is different for specimens located in the different parts of the tree. Next step of the study will be to develop a model of growth stress generation, which will be able to represent this prestressed state of wood. The recovery of locked-in strain is thermo-activated, and depends on a relaxation time (short term to long term mechanisms), so it's interesting to study the strain rate as a function of temperature. Fig. 5 presents strain rate as a function 
of temperature for the 3 types of wood. The thermal activation depends on the radial position of wood and the succession of two inflexion points suggest that two mechanisms with two relaxation times are relaxed. A deeper analyse of the signal in relation to constitutive equation of the material should lead to the identification of locked-in strains spectral distribution.

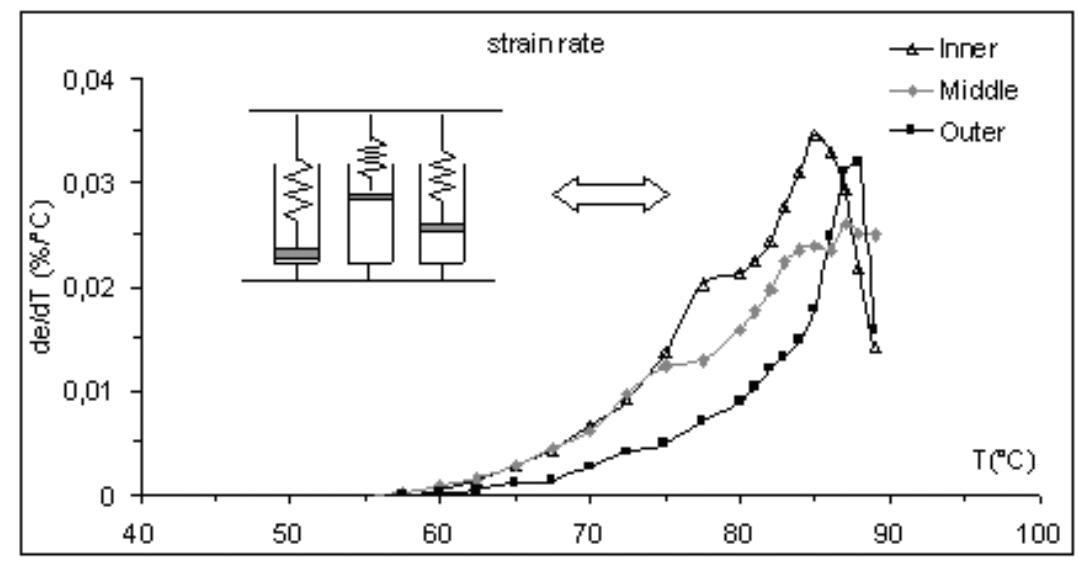

Fig. 5. Strain rate as a function of temperature.

\section{Conclusion}

A procedure allowing to separate the pure HTR from the total thermal strain measured has been described. Because of the difference of rheological history between specimens located in the different parts of the tree, we expect to observe corresponding differences in the thermal activation of the recovery process. These results can be used as input into models of growth stress generation in wood stems.

\section{References}

1. Back E.L. and Salmen L. (1982) Glass transitions of wood components hold implications for molding and pulping processes. Tappi Journal. 65(7), 107-110.

2. Goring D.A.I. (1963) Thermal softening of lignin, hemicellulose and cellulose. Pulp and Paper Magazine of Canada. 64, T517-527.

3. Kübler H. (1959) Studies on growth stresses in trees: 1-2-3, Holz als Roh-und Werkstoff, 17, 1-9, 44-54, 77-86.

4. Yokota T. (1962) Changes in dimension on heating green wood, Forest Products Journal,12 (1), 43-45.

5. Gril J. and Thibaut B. (1994) Tree mechanics and wood mechanics: relating hygrothermal recovery of green wood to the maturation process, Annales des Sciences Forestières, 51, 329-338.

6. Sasaki Y. and Okuyama T. (1983) Residual stress and dimensional change on heating green wood, Mokuzai Gakkaishi, 29(4), 302-307. 
7. Gril J., Berrada E., Thibaut B. and Martin G. (1993) Recouvrance hygrothermique du bois vert. I. Influence de la température. Cas du jujubier (Ziziphus lotus L. Lam.), Annales des Sciences Forestières, 50, 57-70. 